\title{
LYME DISEASE LIKE SYNDROME ASSOCIATED LYMPHOCYTOMA: FIRST CASE REPORT IN BRAZIL
}

\author{
Natalino Yoshinari, Mariana Spolidorio, Virginia Lucia Bonoldi, Miriam Sotto
}

\section{INTRODUCTION}

The tick-borne disease found in Brazil, initially discovered in 1992, has been named Lyme Disease like syndrome (LDLS), because the clinical manifestations are similar with those observed in the Northern hemisphere, but the etiological agent was never isolated and polymerase chain reactions (PCR) with specific or broad recognizing primers of genera Borrelia were always negative in patients and ticks samples. ${ }^{1-9}$

Lymphocytoma cutis (LC) is considered as the stereotype example of the cutaneous B-cell pseudolymphoma. This lesion also designated as "Borrelia/Borrelial lymphocytoma", represents the less common manifestation within the spectrum of $B$. burgdorferi-associated skin diseases. ${ }^{10-13}$ We describe for the first time a clinical case of Borrelia lymphocytoma in Brazil.

\section{CASE DESCRIPTION}

VLBV, a 34 year old woman, lives in the city of Teresópolis, Rio de Janeiro. On January 2003, she came from a walk through Petrópolis, and noticed a tick on her left ankle. After 10 days, she perceived the appearance of vesicular lesions that started to rise, turning into blisters about 3 or $4 \mathrm{~cm}$ in diameter (Figure 1). After almost three weeks, she developed important pain in the knees and hips, so that she looked for a rheumatologist, but all laboratorial results were negative.

Due to the suspicion of Lyme disease, the patient's serum was sent to Pasteur Institute, Paris, France, where a strongly positive serology to Borrelia burgdorferi was detected. On February 2003, less than one month after the tick bite, the patient began treatment with doxycycline $100 \mathrm{mg}$ twice a day. A new sample of serum was delivered to the Laboratory of Rheumatology, of São Paulo University Medical School. The positive serology for $B$.

Department of Medicine - Rheumathology São Paulo University Medical School, São Paulo/SP, Brazil

Email: lyme@lim17.fm.usp.br burgdorferi was confirmed and she was guided to take ceftriaxone, for 20 days, maintaining the doxycycline for 90 days, because she was having a bad evolution, including episodes of cardiac arrhythmia.

Forty days after beginning with doxycycline, her condition improved, and it was decided that the residual blistered lesion should be dried up. Histopathological analysis revealed an epidermis with fragments of rectification of the interpapilar cones and hiperqueratosis. Subepidermis showed a crack or a gap without content. Dermis showed a moderated lymphocytic infiltrate either interstitial, perivascular, nodular or centralized. Occasionally, polimorphonuclear cells and plasma cells were observed.

A review of the slides was requested to a pathologist from Hospital das Clínicas, São Paulo University Medical School, who described epidermis with irregular acantosis and a mononuclear inflammatory infiltrate, consisted by lymphocytes, histiocytes and rare eosinophils (Figures 2, $3,4)$.

More than 2 years after the beginning of the disease, the patient is having a good clinical follow up.

Conclusion: Cutaneous lymphoid hyperplasia, which can be a histological aspect of Lyme disease, can vary and includes the description above, but can have association with B-lymphoma.

\section{DISCUSSION}

The patient described in the present manuscript presented typical epidemiological evidence, associated with skin lesions, arthritis and cardiac arrhythmia. Serological tests for B. burgdorferi antibodies confirmed diagnosis of LDLS. A western blotting (WB) assay perfomed in São Paulo revealed the presence of four bands for IgM class antibodies.

In a study done with 106 cases of lymphocytoma cutis associated to the infection by B. burgdorferi, histopathological analysis revealed the presence of an infiltrate constituted of small lymphocytes, histiocytes, eosinophils and plasma cells at the interpholicular regions. Out of these 


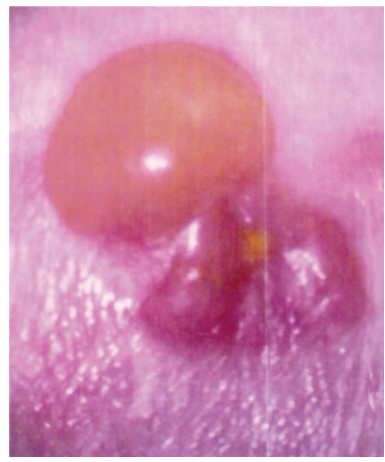

Figure 1 - Vesicular lesion with almost 3 or $4 \mathrm{~cm}$ and blister aspect.

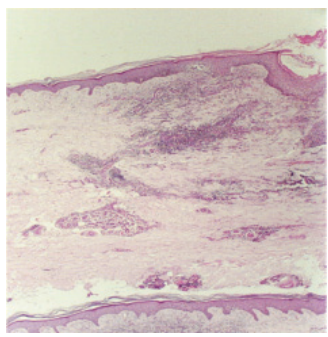

Figure 2 - Skin fragment demonstrating irregular acantosis on the epidermis. Mononuclear inflammatory infiltrate which follows the course of the skin blood vessels. (40X). cases, 99.9\% presented plasma cells and 84.2\% presented eosinophils. As regards serology, performed with $B$. burgdorferi, $17 \%$ of the patients were IgM positive, $78.7 \%$ IgG positive and only $4.3 \%$ were negative. ${ }^{10}$

The distinction between primary cutaneous B-cell lymphoma and B-cell pseudolymphoma on a histological basis may be difficult, particularly in some cases of $B$. burgdorferi-associated lymphoid proliferations ${ }^{14}$. Medical literature includes some cases where patients with pseudolymphoma progressed, after some years, to a malignant lymphoma and death. ${ }^{15}$

In a German study with children who presented lym-

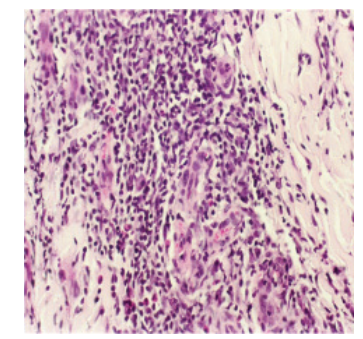

Figure 3 - Dense inflammatory infiltrate composed by lymphocytes, histiocytes and rare eosinophils, around the skin blood vessels with a strong thickness of the walls. (250X).

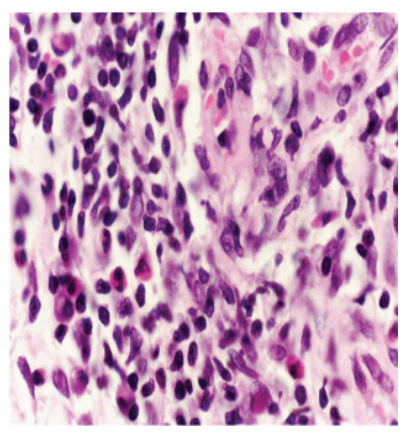

Figure 4 - Detail of the inflammatory infiltrate around the skin blood vessels. (400X).

phocytoma cutis and positive serology for Lyme disease, it was noticed that the ECM may precede the appearance of Borrelia lymphocytoma in the majority of the cases, but there are some reports of occurrence of both at the same time. ${ }^{12}$

When serial serology was done in our patient, the ELISA and WB patterns changed, as the disease got better. Serologic follow up is very important to confirm LDLS and also to predict clinical prognosis. This is the first report of Borrelia lymphocytoma in our country and it reinforces the existence of LDLS, a very important emerging tick-borne disease in Brazil, which reproduces most of symptoms observed in Lyme disease.

\section{REFERENCES}

1. Steere AC, Malawista SE, Hardin JA, Ruddy S, Askenase W, Andiman WA: Erythema Chronicum Migrans and Lyme Arthritis: the enlarging clinical spectrum, Ann. Intern. Med. 1977; 86: 685-98.

2. Yoshinari NH, Steere AC, Cossermelli W: Revisão de borreliose de Lyme, Rev Ass Med Brás. 1989; 35: 34-8.

3. Yoshinari NH, Barros PJL, Cruz FCM, Oyafuso LK, Mendonça M, Baggio D et. al.: Clínica e sorologia da doença de Lyme no Brasil, Rev Bras Reumatol. 1992; 4: 32: 57.

4. Yoshinari NH, Barros PJL, Fonseca AH, Bonoldi VLN, Barros-Batesti DM, Schumaker TTS et al.: Borreliose de Lyme. Zoonose emergente de interesse multidisciplinar, Newslab. 1995; 12:90-104.

5. Yoshinari NH, Barros PJL, Bonoldi VLN: Perfil da borreliose de Lyme no Brasil, Rev Hosp Clin Fac Med S Paulo. 1997; 52:111-17.

6. Yoshinari NH, Barros PJL, Gauditano G, Fonseca AH: Report of 57 cases of Lyme-like disease (LLD) in Brazil, Arthritis Rheum (Suppl). 1999; 43:S188

7. Yoshinari NH, Bonoldi VLN, Barros-Battesti DM, Schumaker TTS: Doença de Lyme-símile no Brasil, Rev Bras Reumatol. 1999; 39(2):578

8. Costa IP, Bonoldi VLN, Yoshinari NH: Perfil clínico e laboratorial da Doença de Lyme-símile no Estado de Mato Grosso do Sul: análise de 16 pacientes, Rev Bras Reumatol. 2001; 41:142-150.
9. Costa IP: Pesquisa de Anticorpos anti Borrelia e do Agente Etiológico, em soro e líquor de pacientes com manifestações clínicas compatíveis com a Doença de Lyme, no Estado de Mato Grosso do Sul, PhD Thesis, School of Medicine, São Paulo University. 1998; 125pp.

10. Colli C, Leinweber B, Mullegger R, Chott A, Kerl H, Cerroni L.: Borrelia burgdorferi-associated lymphocytoma cútis: clinicopathotolic, immunophenotypic, and molecular study of 106 cases, J Cutan Pathol. 2004; 31:232-240.

11. Baranton G, Postic D, Saint Girons I, Boerlin P, Piffaretti JC, Assous M et al.: Delineation of Borrelia burgdorferi sensu stricto, Borrelia garinii sp. Nov., and group VS461 associated with Lymeborreliosis, Int J Syst Bacteriol. 1992; 42: 378-383.

12. Picken RN, Strle F, Ruzic-Sabljic E, Maraspin V, Lotric-Furlan S, Cimperman J et al.: Molecular subtyping of Borrelia burgdorferi sensu lato isolates from five patients with solitary lymphocytoma, J Invest Dermatol. 1997; Jan; 108(1):92-7.

13. Pohl-Koppe A, Wilske B, Weiss M, Schmidt H.: Borrelia lymphocytoma in childhood, Pediatr Infect Dis J. 1998; 17(5): 423-426.

14. Cortijo AT, Medina AO: B-pseudolymphoma: lymphocytoma, Med Cutan Ibero Lat Am. 1986; 14(6):371-86.

15. Grange F, Wechsler J, Guillaume JC, Tortel J, Tortel MC, Audhuy B et al.: Borrelia burgdorferi-associated lymphocytoma cutis simulating a primary cutaneous large B-cell lymphoma, J Am Acad Dermatol. 2002; Oct;47(4):530-4. 